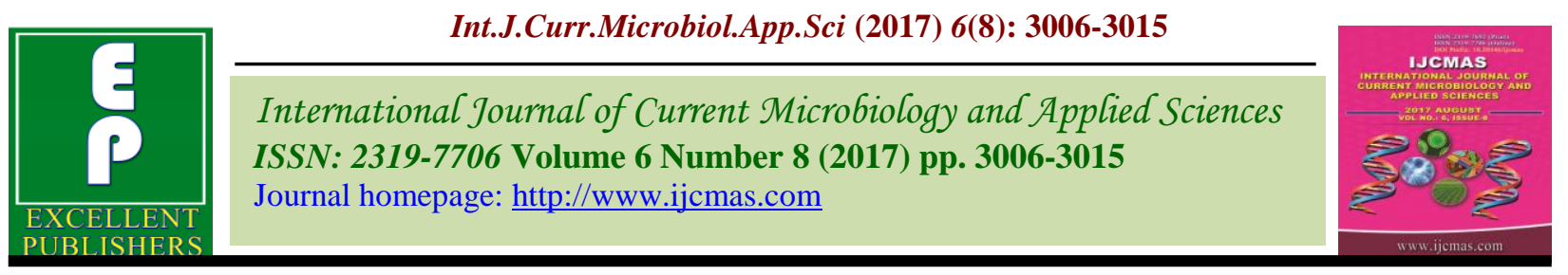

Original Research Article

https://doi.org/10.20546/ijcmas.2017.608.360

\title{
Population Dynamics of Pink Stem Borer on Maize Crop and its Correlation with Prevailing Abiotic Parameters
}

\author{
Sonali Deole*, V.K. Dubey and D.K. Rana \\ Department of Entomology, Indira Gandhi Krishi Vishwavidyalaya, Raipur, \\ Chhattisgarh-492012, India \\ *Corresponding author
}

\begin{tabular}{l} 
Ke y w or d s \\
Maize, Pink stem \\
borer, Population \\
Dynamics, \\
Weather \\
Parameters. \\
\hline Article Info \\
\hline $\begin{array}{l}\text { Accepted: } \\
\text { 23 June 2017 } \\
\text { Available Online: } \\
\text { 10 August } 2017\end{array}$ \\
\hline
\end{tabular}

A B S T R A C T

Population dynamics studies of pink stem borer was carried out during spring seasons of the year 2013-14 and 2014-15 at the Research cum Instructional Farm, IGKV, Raipur (C.G.). Larval population increased gradually and reached to a peak of 13.81 and 18.56 larvae /plant in 56 days $\left(12^{\text {th }}\right.$ SMW) and 49 days (11th SMW) in spring season during 2013-14 and 2014-15, respectively. The maximum adult population was trapped during fourth week of March $\left(13^{\text {th }}\right.$ SMW) and third week of March $\left(12^{\text {th }} \mathrm{SMW}\right)$, when the mean maximum $29.7^{\circ} \mathrm{C}$ and $36.4^{\circ} \mathrm{C}$ and minimum temperatures were 16.4 and $19.4^{\circ} \mathrm{C}$ and with mean relative humidities of 67 and 47.5 per cent during the years 2013-14 and 2014-15, respectively. The interactions between the larval population and weather parameters revealed non-significant correlation. The interactions between the adult population and weather parameters during spring 2013 and 2014 revealed negative and significant and non-significant correlation with maximum temperature $(r=-0.6519$ and -0.4964$)$, negative and significant correlation with minimum temperature $(r=-0.682$ and $r=-0.566)$ while the interactions with morning and evening relative humidity was positive as well as significant with morning relative humidity $(r=0.610$ and 0.649$)$ but nonsignificant with evening relative humidity, respectively.

\section{Introduction}

Maize (Zea mays L.) or corn is a grass of the family Poaceae grown primarily for its kernel. Maize is composed of 71.5 per cent starch, 1.9 per cent protein, 4.8 per cent fat and 1.4 per cent ash (Rathore, 2001). In Chhattisgarh, maize occupies an area of 242.52 thousand ha with an average productivity of $1935 \mathrm{~kg} / \mathrm{ha}$ (Anonymous, 2015).

The replacement of traditional local cultivars with the commercial varieties and hybrids led to expansion of arthropod pest complex as pests of minor importance are now assuming major status. The scenario with respect to insect pests of this crop has changed a lot in the recent past owing to increased area under single cross hybrids and monocropping practiced by the farmers using indiscriminate quantity of insecticides and chemical fertilizers. Insects attack maize throughout the cropping cycle and during storage, resulting in as little as $10 \%$ to complete loss (Bergvinson et al., 2002). During the winter season pink borer with more extensive 
coverage, may cause damage up to $78.9 \%$ to the crop. It is a pertinent point to note that productivity of maize in peninsular India is higher than the northern states, and that of winter maize (3.22 t/ha) is higher than the rainy season maize (1.74 t/ha). Thus, to stabilize the maize production effective control of pink borer is of immense importance (Santosh et al., 2012). Changing climatic scenario with modern cultivation practices in rice crop made pink stem borer to achieve pest status in many rice growing regions of India (Sampath et al., 2014). The occurrence of pink stem borer in relation to weather parameters provides information on the initiation and extent of damage which is useful for the effective management and formulation of IPM strategies on maize.

\section{Materials and Methods}

A plot size of $200 \mathrm{~m}^{2}$ with sugar - 75 popular hybrid was raised and maintained without insecticide application to study the occurrence of major insect pests on maize in relation to abiotic factors viz., maximum temperature, minimum temperature, relative humidity (morning and evening).The spring maize crop was sown on 22-01-2013 and 23-01-2014 following standard agronomical practices. The incidence of pink stem borer were recorded soon after noticing the initial infestation and continued up to the maturity of the crop at weekly intervals throughout the growing season.

The occurrence of maize pink stem borer, $S$. inferens, was observed by destructive sampling of 25 randomly selected plants at five different locations @ five plants at each location of plot. Then the stems were split open to count the number of larvae of Sesamia inferens at seven days interval starting from seven days after germination till harvest of the crop. The seasonal population fluctuations of maize pink stem borer moth recorded through light trap. The collections were made throughout the crop season. Number of pink stem borer, weekly catches was correlated with the abiotic factors. Meteorological data were received from Department of Agro meteorology, IGKV, Raipur and were utilized for correlations and regression studies viz. the cumulative and individual effects of temperature and relative humidity on population buildup of $S$. inferens. The influence of abiotic factors on the occurrence of pink stem borer of maize was statistically analyzed by subjecting the number of insects per plant and weather data to simple correlation and multilinear regression analysis (Gomez and Gomez, 1994).

\section{Results and Discussion}

The initial occurrence of $S$. inferens during spring season 2013-14 was observed during the first week of February ( $6^{\text {th }}$ SMW) i.e., at 14 days after germination with a mean population of 3.82 larvae/plant. The average maximum and minimum temperatures prevailing during the initial infestation were $28.8{ }^{\circ} \mathrm{C}$ and $11.4{ }^{\circ} \mathrm{C}$, respectively. While, the average morning and evening relative humidity were 84 and 31 per cent respectively. The pest population increased gradually and reached to a peak on $12^{\text {th }} \mathrm{SMW}$ i.e., 56 days after germination with a mean population of 13.81 larvae /plant. The average maximum and minimum temperatures prevailed during this period were $36.4{ }^{\circ} \mathrm{C}$ and $20.2{ }^{\circ} \mathrm{C}$, respectively and the average morning and evening relative humidity were 66 and 22 per cent, respectively. Thereafter, the pest population was more or less uniform up to $14^{\text {th }}$ SMW i.e., tasseling stage of the crop with 11.81 larvae/ plant, when the average maximum and minimum temperatures ranged between $38.1{ }^{0} \mathrm{C}$ to $38.7{ }^{0} \mathrm{C}$ and $22.7{ }^{0} \mathrm{C}$ to $21.5{ }^{\circ} \mathrm{C}$, respectively and the average morning and evening relative humidity were ranged 
between 62 to 58 and 17 to 28 per cent, respectively. The pest population declined gradually with the rise in maximum and minimum temperatures and reached to a minimum (1.00 larvae per plant) by $19^{\text {th }}$ SMW, when the average maximum and minimum temperatures were $43.6{ }^{\circ} \mathrm{C}$ and 27.2 ${ }^{0} \mathrm{C}$ and the average morning and evening relative humidity were 48 and 17 per cent, respectively (Figs. 1 and 2).

The adult moth appeared for the first time in the light trap during $5^{\text {th }}$ SMW (19 adults) when the mean maximum and minimum temperatures $\left(28.8\right.$ and $\left.11.4^{\circ} \mathrm{C}\right)$ and the average morning and evening relative humidity were 84 and 31 per cent, respectively. Maximum traps (44 adults / week) were observed during $11^{\text {th }}$ SMW, when, average maximum and minimum temperature $\left(29.7^{\circ} \mathrm{C}\right.$ and $\left.16.4{ }^{\circ} \mathrm{C}\right)$ and the average morning and, evening relative humidity were 87 and 47 per cent, respectively. After $15^{\text {th }} \mathrm{SMW}$, number of adults decreased gradually to 2 pink borer moths/ week in $18^{\text {th }}$ SMW when the maximum and minimum temperature (43.1 and $27.6^{\circ} \mathrm{C}$ ) and the average morning and evening relative humidity were 51 and 21 per cent, respectively.

Similarly, during the second year of study i.e. 2014-15, the pink stem borer larvae presence on the maize crop was noted in the first week of February ( $6^{\text {th }}$ SMW) i.e., at 14 days after germination with a weekly mean population of 4.16 larvae/ plant. The average maximum and minimum temperatures prevailed during the initial infestation were $31.7{ }^{\circ} \mathrm{C}$ and 14.8 ${ }^{0} \mathrm{C}$, respectively. While, the average morning and evening relative humidity were 85 and 33 per cent, respectively. The pest population increased gradually and reached to a peak during $11^{\text {th }}$ SMW i.e., 49 days after germination with a mean population of 18.56 larvae /plant. The average maximum and minimum temperatures prevailed during this period were $33.3{ }^{\circ} \mathrm{C}$ and $19.5{ }^{\circ} \mathrm{C}$, respectively and the average morning and evening relative humidity were 89 and 38 per cent, respectively. Thereafter, the pest population was more or less uniform up to fourteenth standard week $\left(14^{\text {th }}\right.$ SMW) i.e., tasseling stage of the crop with 10.67 larvae/ plant, when the average maximum and minimum temperatures ranged between $38.4^{\circ} \mathrm{C}$ and $39.5^{\circ} \mathrm{C}$ and $22.2^{\circ} \mathrm{C}$ and $22.0^{\circ} \mathrm{C}$, respectively and the average morning and evening relative humidity were ranged between 67 and 59 and 24 and 17 per cent, respectively.

The pest population declined gradually with the rise in maximum and minimum temperatures and reached to a minimum 1.67 larvae/ plant by $18^{\text {th }}$ SMW, when the average maximum and minimum temperatures were $40.1^{\circ} \mathrm{C}$ to $25.6^{\circ} \mathrm{C}$ and the average morning and evening relative humidity were 53 and 23 per cent, respectively.

During 2014-15 the pink stem borer adults were recorded throughout during growing season in the light trap. Maximum adults (39 adults /week) were trapped during $12^{\text {th }}$ SMW, when average maximum and minimum temperatures ( 36.4 and $19.4{ }^{\circ} \mathrm{C}$ ) and average morning and evening relative humidity were 74 and 21 per cent, respectively. After $14^{\text {th }}$ SMW, number of adults decreased gradually to 1 pink borer moth/week in $19^{\text {th }} \mathrm{SMW}$, when the maximum and minimum temperature $\left(38.1\right.$ and $\left.26.0^{\circ} \mathrm{C}\right)$ and the average morning and evening relative humidities were 59 and 27 per cent, respectively.

The data of both the spring seasons suggested that the infestation of pink stem borer larvae initiated during the first week of February $\left(6^{\text {th }}\right.$ SMW) i.e., 14 days after germination. The larval population increased gradually and reached to a peak of 13.81 and 18.56 larvae 
/plant in 56 and 49 days in spring season during 2013-14 and 2014-15, respectively. The pest population declined gradually with the rise in maximum and minimum temperatures and reached to its minimum population (1.00 and 1.67 larvae /plant) in first week of May during both the years.

Data for two years revealed that the pink stem borer adults active throughout the cropping period. The maximum adult population was recorded during $11^{\text {th }}$ and $12^{\text {th }}$ SMW for 2013 -
14 and 2014-15, respectively. When the mean maximum $\left(29.7^{\circ} \mathrm{C}\right.$ and $\left.36.4^{\circ} \mathrm{C}\right)$ and minimum temperatures $\left(16.4\right.$ and $\left.19.4{ }^{\circ} \mathrm{C}\right)$ with mean relative humidity (67 and 47.5 per cent). Thereafter, during spring 2013-14 and 201415 the adult traps decreased gradually till $18^{\text {th }}$ and $19^{\text {th }}$ SMW when the mean maximum and minimum temperature $\left(40.6\right.$ and $\left.26.8^{\circ} \mathrm{C}\right)$ and the average morning and evening relative humidity were 55 and 24 per cent, respectively (Figs. 1 and 2).

Table.1 Population dynamics of Sesamia inferens larvae and adult in relation to abiotic Parameters during spring 2013-14

\begin{tabular}{|c|c|c|c|c|c|c|c|}
\hline \multirow[t]{2}{*}{ SMW } & \multirow[t]{2}{*}{ Duration } & \multicolumn{2}{|c|}{$\begin{array}{l}\text { Temperature } \\
\left({ }^{0} \mathrm{C}\right)\end{array}$} & \multicolumn{2}{|c|}{$\begin{array}{l}\text { Relative } \\
\text { Humidity (\%) }\end{array}$} & \multirow[t]{2}{*}{$\begin{array}{l}\text { Number of } \begin{array}{l}\text { Sesamia } \\
\text { inferens } \\
\text { Plant/week }\end{array} \\
\end{array}$} & \multirow[t]{2}{*}{$\begin{array}{lr}\text { Total } & \text { adult } \text { light } \\
\text { trap } & \text { catches/ } \\
\text { Week } & \end{array}$} \\
\hline & & Max & Min & $\begin{array}{c}\text { I } \\
\text { (Mor.) }\end{array}$ & $\begin{array}{c}\text { II } \\
\text { (Eve.) }\end{array}$ & & \\
\hline 4 & Jan22-28 & 27.0 & 12.2 & 81 & 36 & - & - \\
\hline 5 & Jan29-Feb 04 & 28.8 & 11.4 & 84 & 31 & - & 19 \\
\hline 6 & Feb 05-11 & 30.0 & 16.8 & 86 & 44 & 3.82 & 20 \\
\hline 7 & Feb 12-18 & 29.7 & 16.4 & 87 & 47 & 4.88 & 26 \\
\hline 8 & Feb 19-25 & 29.8 & 14.6 & 84 & 36 & 8.62 & 32 \\
\hline 9 & Feb 26-Mar 04 & 32.3 & 13.8 & 79 & 22 & 13.71 & 38 \\
\hline 10 & Mar.05-11 & 34.3 & 14.8 & 71 & 19 & 12.62 & 37 \\
\hline 11 & Mar.12-18 & 33.8 & 20.4 & 70 & 31 & 12.18 & 44 \\
\hline 12 & Mar.19-25 & 36.4 & 20.2 & 66 & 22 & 13.81 & 26 \\
\hline 13 & $\begin{array}{l}\text { Mar.26-Apr. } \\
01\end{array}$ & 38.1 & 22.7 & 62 & 21 & 7.82 & 37 \\
\hline 14 & April 02-08 & 38.7 & 21.5 & 58 & 17 & 11.81 & 21 \\
\hline 15 & April 09-15 & 39.9 & 24.7 & 57 & 28 & 6.12 & 10 \\
\hline 16 & April 16-22 & 38.0 & 21.9 & 63 & 28 & 5.52 & 9 \\
\hline 17 & April 23-29 & 38.1 & 24.4 & 64 & 29 & 8.55 & 4 \\
\hline 18 & $\begin{array}{l}\text { Apr. 30-May } \\
06\end{array}$ & 43.1 & 27.6 & 51 & 21 & 2.56 & 2 \\
\hline 19 & May 07-13 & 43.6 & 27.2 & 48 & 17 & 1.00 & 0 \\
\hline \multirow[t]{3}{*}{20} & May 14-20 & 43.3 & 27.9 & 44 & 15 & 0.0 & \\
\hline & & & \multicolumn{3}{|c|}{ Overall seasonal mean } & 7.063 & 13.62 \\
\hline & \multicolumn{5}{|c|}{$\begin{array}{l}\text { Correlation coefficient values (r) } \\
\text { Maximum Temperature } \\
\text { Minimum Temperature } \\
\text { Morning relative humidity } \\
\text { Evening relative humidity }\end{array}$} & $\begin{array}{c}-0.23 \mathrm{NS} \\
-0.31 \mathrm{NS}-0.22 \mathrm{NS} \\
-0.12 \mathrm{NS}\end{array}$ & $\begin{array}{c}-0.65 * * \\
-0.68 * * \\
0.61 * \\
0.21 \text { NS }\end{array}$ \\
\hline
\end{tabular}


Table.2 Population dynamics of Sesamia inferens larvae and adult in relation to abiotic Parameters during spring 2014-15

\begin{tabular}{|c|c|c|c|c|c|c|c|}
\hline \multirow[t]{2}{*}{ SMW } & \multirow[t]{2}{*}{ Duration } & \multicolumn{2}{|c|}{$\begin{array}{l}\text { Temperatur } \\
\text { e } \\
\left({ }^{0} \mathrm{C}\right)\end{array}$} & \multicolumn{2}{|c|}{$\begin{array}{l}\text { Relative Humidity } \\
(\%)\end{array}$} & \multirow[t]{2}{*}{$\begin{array}{l}\text { Number } \\
\text { larvae/ } \\
\text { Plant/week }\end{array}$} & \multirow[t]{2}{*}{$\begin{array}{l}\text { Total light trap } \\
\text { catches (Adult / Week) }\end{array}$} \\
\hline & & Max. & Min. & $\begin{array}{l}\text { I } \\
\text { (Mor.) }\end{array}$ & II (Eve.) & & \\
\hline 4 & Jan22-28 & 28.2 & 13.7 & 87 & 38 & - & \\
\hline 5 & Jan29-Feb 04 & 28.8 & 10.1 & 86 & 28 & 0 & 20 \\
\hline 6 & Feb 05-11 & 31.7 & 14.8 & 85 & 33 & 4.16 & 16 \\
\hline 7 & Feb 12-18 & 27.9 & 15.4 & 83 & 39 & 4.89 & 22 \\
\hline 8 & Feb 19-25 & 28.9 & 14.6 & 86 & 41 & 6.32 & 31 \\
\hline 9 & Feb 26-Mar 04 & 27.9 & 14.8 & 91 & 61 & 8.54 & 28 \\
\hline 10 & Mar.05-11 & 27.5 & 17.5 & 88 & 44 & 11.90 & 23 \\
\hline 11 & Mar.12-18 & 33.3 & 19.5 & 89 & 38 & 18.56 & 36 \\
\hline 12 & Mar.19-25 & 36.4 & 19.4 & 74 & 21 & 12.66 & 39 \\
\hline 13 & $\begin{array}{l}\text { Mar.26-Apr. } \\
01\end{array}$ & 38.4 & 22.2 & 67 & 24 & 10.53 & 35 \\
\hline 14 & April 02-08 & 39.5 & 22.0 & 59 & 17 & 10.67 & 29 \\
\hline 15 & April 09-15 & 38.5 & 22.4 & 58 & 23 & 6.00 & 12 \\
\hline 16 & April 16-22 & 37.8 & 23.4 & 67 & 28 & 3.05 & 07 \\
\hline 17 & April 23-29 & 41.1 & 25.1 & 58 & 18 & 2.78 & 02 \\
\hline 18 & $\begin{array}{l}\text { Apr. 30-May } \\
06\end{array}$ & 40.1 & 25.6 & 53 & 23 & 1.67 & 01 \\
\hline 19 & May 07-13 & 38.8 & 26.0 & 59 & 27 & 0.00 & 01 \\
\hline \multirow[t]{3}{*}{20} & May 14-20 & 42.1 & 27.1 & 43 & 16 & 0.00 & 00 \\
\hline & & & \multicolumn{3}{|c|}{ Overall seasonal mean } & 6.358 & 18.87 \\
\hline & \multicolumn{5}{|c|}{$\begin{array}{l}\text { Correlation coefficient values (r) } \\
\text { Maximum Temperature } \\
\text { Minimum Temperature } \\
\text { Morning relative humidity } \\
\text { Evening relative humidity }\end{array}$} & $\begin{array}{l}-0.24 \text { NS } \\
-0.18 \text { NS } \\
0.45 \text { NS } \\
0.29 \text { NS } \\
\end{array}$ & $\begin{array}{c}-0.49 * \\
-0.56 * \\
0.64 * * \\
0.37 \text { NS } \\
\end{array}$ \\
\hline
\end{tabular}

*Significant at 5\% level, ** Significant at $1 \%$ level, $\mathbf{N S}=$ non-significant

Table.3 Multiple linear regression analysis of pink stem borer adult population on certain weather parameters

\begin{tabular}{|c|c|c|}
\hline Year & Regression Equation & $\mathbf{R}^{2}$ \\
\hline 2013-14 & $\begin{aligned} & * * \mathrm{Y}= 183.784-7.383 \mathrm{X}_{1}+4.985 \mathrm{X}_{2}+0.935 \mathrm{X}_{3}-2.291 * \mathrm{X}_{4} \\
&(219.49) \\
&\end{aligned}$ & 0.657 \\
\hline 2014-15 & 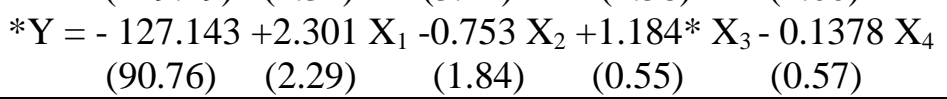 & 0.53 \\
\hline
\end{tabular}

$(* *)=$ Significant at $\mathrm{p} \leq 0.01,(*)=$ Significant at $\mathrm{p} \leq 0.05, \mathrm{Y}=$ larval/adult population, $\mathrm{X}_{1}=$ Maximum Temperature, $X_{2}=$ Minimum Temperature, $X_{3}=$ Morning relative humidity, $X_{4}=$ Evening relative humidity, $R^{2}=$ Coefficient of determination. 
Fig.1 Influence of weather parameters on populations of other insect pests on maize during spring season (2013-2014)

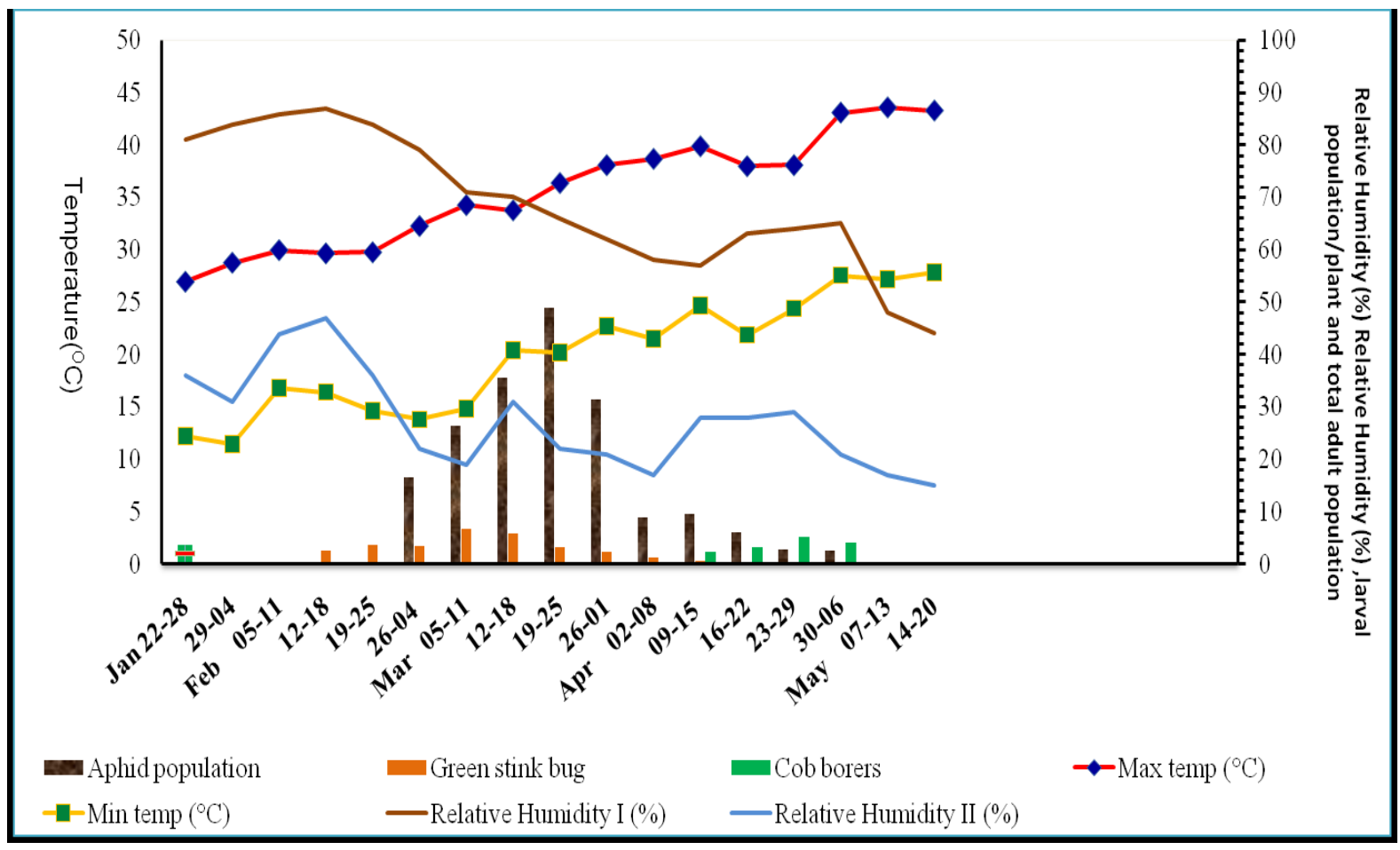

Fig.2 Influence of weather parameters on populations of other insect pests on maize during spring season (2014-2015)

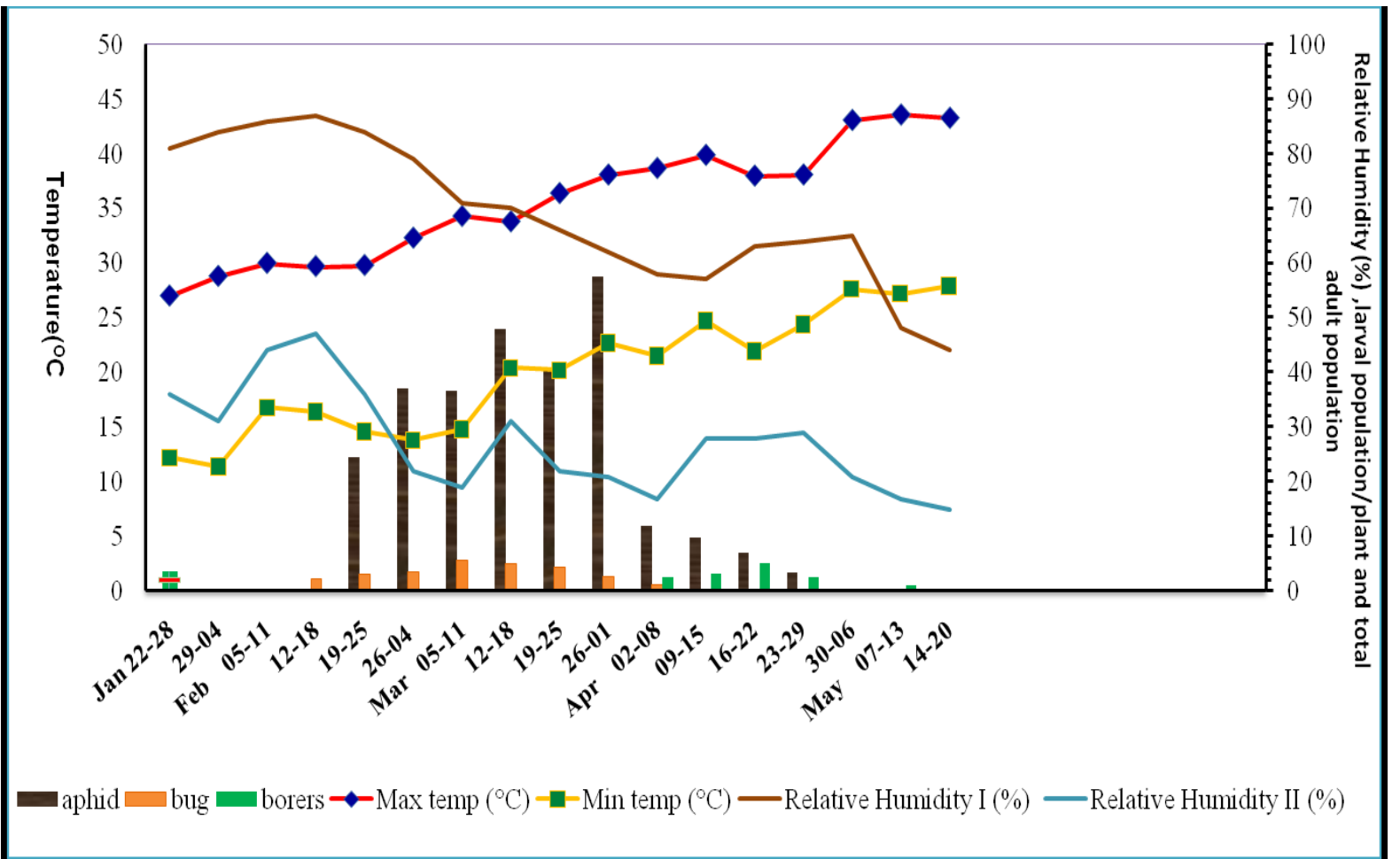


Fig.3 Regression of Sesamia inferens adult on abiotic parameters (2013-14)

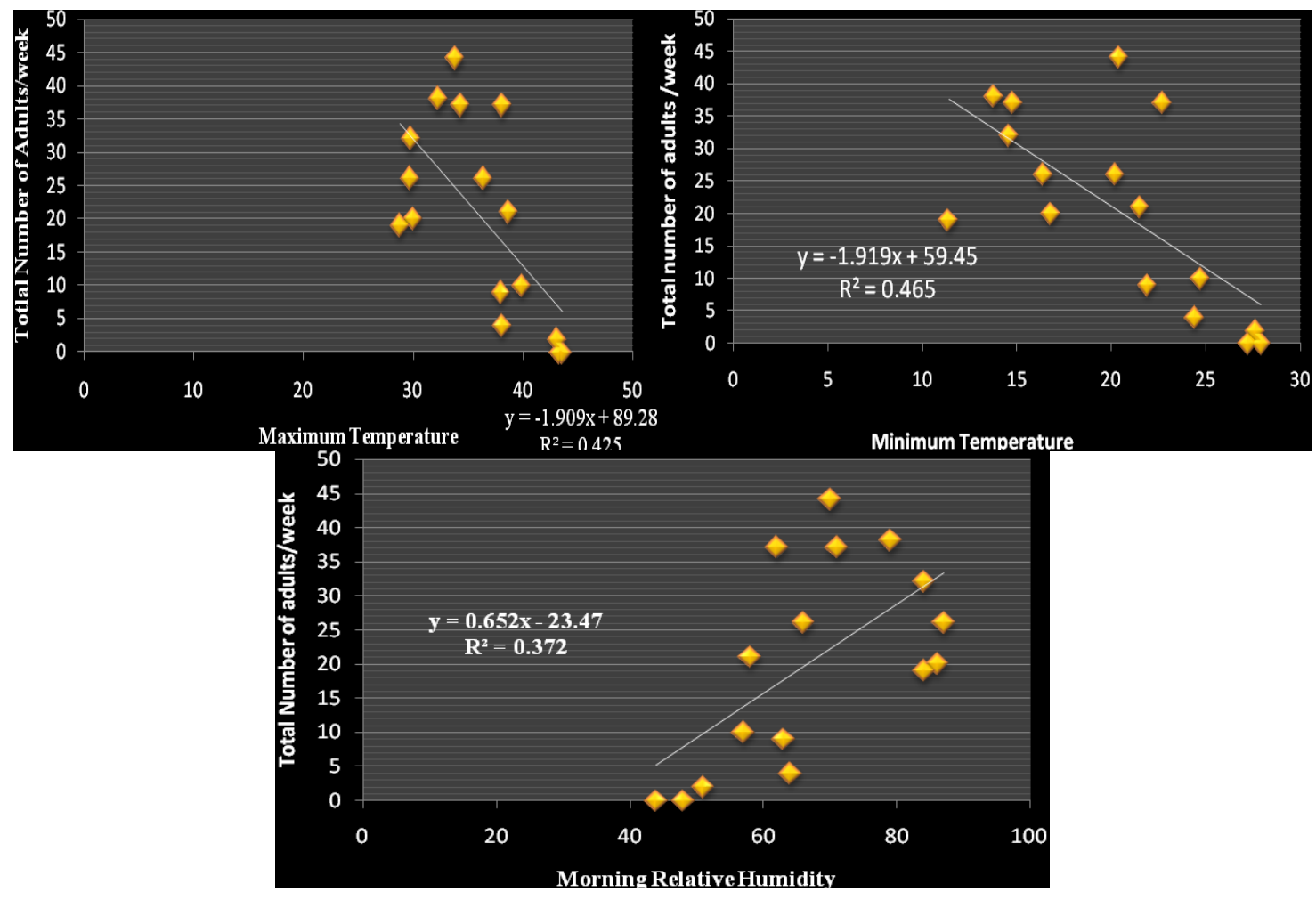

Fig.4 Regression of Sesamia inferens adult on abiotic parameters (2014-15)

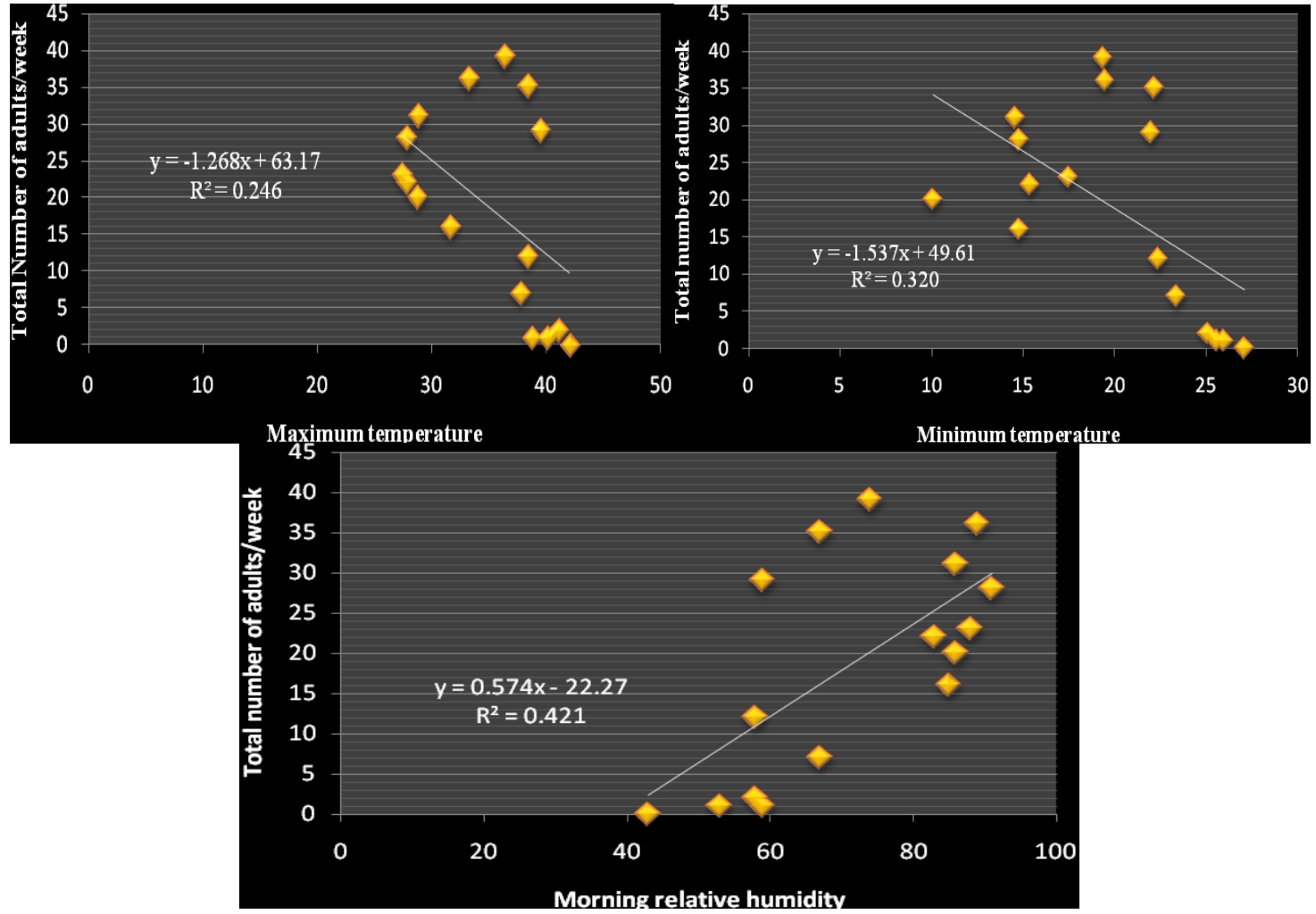


This study was in agreement with the observation made by Jalali and Singh (2002) they observed the occurrence of $C$. partellus started during the third week of December i.e., 28 days after sowing (three weeks after crop emergence). Kandalkar et al., (1996) also observed that the peak infestation of $C$. partellus from 31-60 days after sowing at Akola during kharif season. Mahadevan and Chelliah (1986) also observed the peak infestation of stem borer at 30-45 days after sowing in Coimbatore. There after the pest population declined gradually at harvesting stage where 0.8 larvae/ plant. These findings were also confirmed with the work of Timaru et al., (2012) as most suitable condition for Chilo partellus Swinehoe development was 26 to $30{ }^{\circ} \mathrm{C}$ temperature. Regarding the maize growing season, mean of the weeks revealed that borer damage was comparatively less $(22.5 \%)$ at $21.1{ }^{\circ} \mathrm{C}$ during winter seeded maize plants than spring $\left(47.08 \%\right.$ at $\left.28.78{ }^{\circ} \mathrm{C}\right)$ and rainy $\left(47.03 \%\right.$ at $\left.29.2{ }^{\circ} \mathrm{C}\right)$. The above statement is supported by Muhammad et al., 2010 that the infestation of Chilo partellus Swinehoe was found highest at higher temperature $\left(32.5^{\circ} \mathrm{C}\right)$. The results are also in close approximation with Thakur et al., (2013) that the insect's injury was approximately in the same trend in both the years proportional to prevailing temperature. Percentage stem borer infestation was gradually increased toward the progress of weeks and more or less remained constant from 10 to 42 weeks and further started declining gradually. Thus, the temperature was pronounced resulting in higher percentage of infestation. Zafar and Chaudhry (1979) observed moth populations of the pink borer Sesamia inferens were highest in March and October; moths also emerged in February and November in both 1972 and 1973. S. inferens requires comparatively lower temperature for emergence than Scirpophaga spp. Mahesh et al., (2013) assessed pink borer damage in sugarcane crop and found the maximum damage from March to May (peak period of its activity) as percent dead hearts from the number of damaged shoots with dead hearts and total number of shoots in different accessions.

Ahad et al., (2008) also recorded the population of adult stem borer appeared throughout the growing season with their respective peaks of 49 and 47 adults/ trap during 2006 and 2007 and infestation of stem borer was recorded from $3^{\text {rd }}$ week of crop season till harvest.

\section{Correlation of pink stem borer (larvae and} adult) and regression of adult population with certain weather parameters

The interactions between the larval population of $S$. inferens and weather parameters during spring 2013-14 and 2014-15 revealed nonsignificant correlation with maximum temperature, minimum temperature, morning and evening relative humidities.

The interactions between the adult population of $S$. inferens and weather parameters during spring 2013-14 revealed negative and significant correlation with maximum temperature $(\mathrm{r}=-0.6519)$, minimum temperature $(\mathrm{r}=-0.682)$ while, the interactions with morning and evening relative humidity were positive as well as significant with morning relative humidity ( $\mathrm{r}$ $=0.610)$ but non-significant with evening relative humidity $(\mathrm{r}=0.2135)$ (Table 1$)$.

During spring 2014-15, the interactions between the adult population of $S$. inferens and weather parameters (Table 2) revealed negative and significant correlation with maximum temperature $(\mathrm{r}=-0.4964)$ and minimum temperature $(\mathrm{r}=-0.566)$ while, the interactions with morning humidity was positive as well as significant $(r=0.649)$ and with evening relative humidity it shows non - 
significant correlation( $\mathrm{r}=0.379)$.Similarly, Kandalkar and Men (2004) also recorded negative and non-significant correlation $(\mathrm{r}=$ 0.0128) of Chilo partellus with maximum temperature; negative and significant correlation with minimum temperature and non-significant correlation with morning relative humidity $(\mathrm{r}=0.0150)$.Similarly, Singh and Kular (2015) evaluated the values of correlation coefficient (r) between pink stem borer incidence and maximum, minimum, temperatures with the values of 0.19 and -0.005 , respectively and they were non-significant at $\mathrm{p}=0.05 \%$. The incidence of $S$. inferens has statistically significant and positive correlation $(\mathrm{r}=0.53)$ with relative humidity. Average relative humidity of 80 per cent was favourable for its damage.

The data on $S$. inferens adult incidence when subjected to multiple linear regression analysis. The regression equation was worked out and found that the weather parameters could influence the adult population of $S$. inferens on maize to the extent of 65 per cent $\left(\mathrm{R}^{2}=0.657\right)$ (Table 3 and Fig. 3).

During spring, 2014-15 again, it was found that the weather parameters could influence the adult population of $S$. inferens significantly on maize to the extent of 53 per cent $\left(\mathrm{R}^{2}=0.533\right)($ Fig. 4).

\section{References}

Ahad, I., Bhagat, R. M., Ahmad, H. and Monobrullah, M. 2008. Population dynamics of maize stem borers, Chilo partellus (Swinhoe) in upper Himalayas of Jammu region. J. bio-sci., 16: 137138.

Anonymous, 2015. Report of Agriculture Department, Chhattisgarh Government. Krishi Darshika, Directorate of extension services, IGKV, Raipur (C.G.), p4.
Bergvinson, D.J., Vassal S.K., Singh N.N., Panwar VPS and Sekher J.C. 2002 Advances in conventional breeding for insect resistance in tropical maize. In proceeding of the $8^{\text {th }}$ Asian Regional Maize workshop, Bangkok: 325-332.

Jalali, S. K., and Singh, S. P. 2002. Seasonal activity of stem borers and their natural enemies on fodder maize. Entomon, 27 (2): 137-146.

Kandalkar, H. G., and Men, U. B. 2004. Path coefficient analyses of sorghum stem borer C.partellus incidence $\mathrm{Vs}$ abiotic factors. Insect Environment, 10(2):1920.

Kandalkar, H. G., Men, U. B., Wanjari, S.S., Dhope, A.M., Narkhade, S.S. and Shekhar, V.B. 1996. Effect of weather factors on population of shoot fly and stem borer.P K V Research Journal, 20(1):94-95.

Mahadevan and Chelliah, S. 1986. Influence of season and weather factors on the occurrence of the sorghum stem borer C.partellus in Tamil Nadu.Tropical pest management, 32(3):212-214.

Mahesh, P., Chandran, K., Srikanth, J., Nisha, M., Manjunatha, T. 2013. Natural incidence of Sesamia inferens Walker in sugarcane germplasm. Sugar Tech., 15(4):384-389.

Muhammad, A. Z., Muhammad, A. S., Muhammad, A. R., Hamza, A., Hayat, A., Khan, A. 2010. Effect of temperature and Relative Humidity on population dynamics of some insect pests of maize. Pak. J. life Soc. Sci., $8(1): 16: 18$.

Rathore, M.D., 2001. Ecology of common insect pest of rice. Annu. Rev. Entomol., 13:257-294.

Sampath Kumar, M., Chitra, S., Mohan, M., Padmavathi, Subaharan, K. and Katti, G. 2014. Emergence pattern, reproductive biology and courtship behaviour of rice pink stem borer, 
Sesamia inferens (Walker) (Noctuidae: Lepidoptera). Agrotechnol,.2(4):60.

Santosh, H.B.,

Sekhar, J.C., Rakshit, S., Gadag, R.N. and Dass, S. 2012. Detection of epistatic interaction for susceptibility towards pink borer (Sesamia inferens Walker) in maize (Zea mays L.) Indian J. of Genet, 72(3):284289.

Singh, B., and Kular, J. S. 2015. Influence of abiotic factors on population dynamics of pink stem borer (Sesamia inferens Walker) in rice-wheat cropping system of India. Journal of Wheat Research, $7(2): 23-28$.

Thakur, P., Shrestha, J. Bhandari, G. S. and
Achhami, B. B. 2013. Insect Scenario and Its Succession in Year Round Weekly Interval Seeded Maize Varieties at Rampur, Chitwan, Nepal. International Journal of Modern Plant \& Animal Sciences, 1(2): 96-104.

Timaru, E., Getu, J. B., Bruce, T. 2012. Effect of temperature and relative humidity on the development and fecundity of Chilo partellus (Swinhoe) (Lepidoptera: Crambidae). Bulletin of Entomological Research, 102(1): 9-15.

Zafar, M.A., Chaudhry, N.A. 1979. Moth population fluctuation-a tool for forecasting stem borer outbreaks. International Rice Research Newsletter, 4 (4) 20-21.

\section{How to cite this article:}

Sonali Deole, V.K. Dubey and Rana, D.K. 2017. Population Dynamics of Pink Stem Borer on Maize Crop and Its Correlation with Prevailing Abiotic Parameters. Int.J.Curr.Microbiol.App.Sci. 6(8): 3006-3015. doi: https://doi.org/10.20546/ijcmas.2017.608.360 